\title{
Paleoseismic and Slip-Rate Observations along the Honey Lake Fault Zone, Northeastern California, USA
}

\author{
by R. Turner," R. D. Koehler, R. W. Briggs, ${ }^{\dagger}$ and S. G. Wesnousky
}

\begin{abstract}
The Honey Lake fault is a major strike-slip fault in northeastern California that accommodates northwest-directed right-lateral shear in the northern Walker Lane. We reexamine the fault's paleoseismic history and slip rate by evaluating a natural stream bank exposure of the fault and offset terrace riser. Structural and stratigraphic relations within the modern stream cut, radiocarbon ages, and a detailed topographic survey of the offset terrace riser are used to estimate a Holocene fault slip rate of $1.7-0.6 \mathrm{~mm} / \mathrm{yr}$ or more. We also interpret the occurrence of at least four surface-rupturing earthquakes during the last 7025 calendar years before present (B.P.). Three of the surface-rupturing earthquakes occurred prior to 4670 calendar years B.P. and have interevent times that range between 730 and $990 \mathrm{yr}$. The stratigraphic record is limited after $\sim 4670$ calendar years B.P., and records evidence for at least one more subsequent surface-rupturing earthquake.
\end{abstract}

Online Material: A photomosaic of the Honey Lake fault zone exposure.

\section{Introduction}

The right-lateral Honey Lake fault trends northwest through northeastern California. It is one of several active faults within the northern Walker Lane that accommodate a portion of the approximately $50 \mathrm{~mm} / \mathrm{yr}$ of relative plate motion between the Pacific and North American plates (Fig. 1). Geodetic observations indicate that about $6 \pm 2 \mathrm{~mm} / \mathrm{yr}$, or approximately $10 \%-15 \%$ of this relative motion, is accumulating across the northern Walker Lane (Thatcher et al., 1999; Thatcher, 2003). The Honey Lake fault zone comprises two main strands, a normal range-front fault (Russell, 1885) and a strike-slip strand (Grose et al., 1989; Wills, 1990). The focus of this study is the Holocene-active strike-slip strand, a major structural feature that has accumulated $\sim 9.5-17 \mathrm{~km}$ of post-Oligocene right-lateral offset (Wagner et al., 1989; Hinz, 2004). The fault also deforms late Pleistocene sediments related to pluvial Lake Lahontan, which at its highstand ( $>15,475 \pm 720$ calendar years B.P.) integrated many basins in western Nevada including the Honey Lake, Pyramid Lake, and Winnemucca Lake subbasins (Fig. 1) (Adams and Wesnousky, 1998; Reheis, 1999). A natural exposure of the fault trace and an offset adjacent terrace riser along Long Valley creek (Fig. 2) were the basis for Wills and Borchardt (1993) to interpret at least four surface-rupturing earthquakes since the deposition of the Tsoyawata bed of the Mazama

\footnotetext{
*Present address: William Lettis and Associates, 1777 Botelo Drive, Suite 262, Walnut Creek, California 94596.

'Present address: California Institute of Technology, Tectonics Observatory, MS 100-23, Pasadena, California 91125.
}

tephra (7845 \pm 105 calendar years B.P.; Davis, 1978; Bacon, 1983). They estimate a minimum late Pleistocene slip rate of $1.1-2.6 \mathrm{~mm} / \mathrm{yr}$. We report a reassessment and refinement of the Long Valley creek study site based on the mapping of a new exposure of the natural stream cut created by $\sim 4.5 \mathrm{~m}$ of lateral erosion during a 1998 flood (Wills, 2001). The reexamination includes an introduction of new radiocarbon ages that refine the earthquake history and a detailed topographic survey that illustrates measurements and uncertainties associated with the offset terrace riser.

\section{Natural Stream-Cut Exposure and Paleoseismology}

During the summers of 2004 and 2005, we mapped approximately $40 \mathrm{~m}$ of a new stream-cut exposure of an inset terrace deposit along Long Valley Creek (Figs. 2 and 3). The exposed stratigraphy consists of primarily flat-lying, finegrained fluvial and overbank deposits. Hiatuses in deposition are marked by intervals of weak soil development (Fig. 3). Deposit age control is provided by the Tsoyawata bed of the Mazama tephra at the base of the exposure and by four detrital charcoal pieces that provide accelerator mass spectrometry (AMS) radiocarbon ages in stratigraphic order ranging from $\sim 7025$ to $\sim 4670$ calendar years B.P. (Table 1). Reported ages provide maximum bounds on layer ages because AMS dates are from detrital charcoal and the Tsoyawata ash is reworked. The tephra and radiocarbon ages are consistent with deposition of an inset terrace during a phase of midHolocene aggradation of Long Valley Creek. A photomosaic 


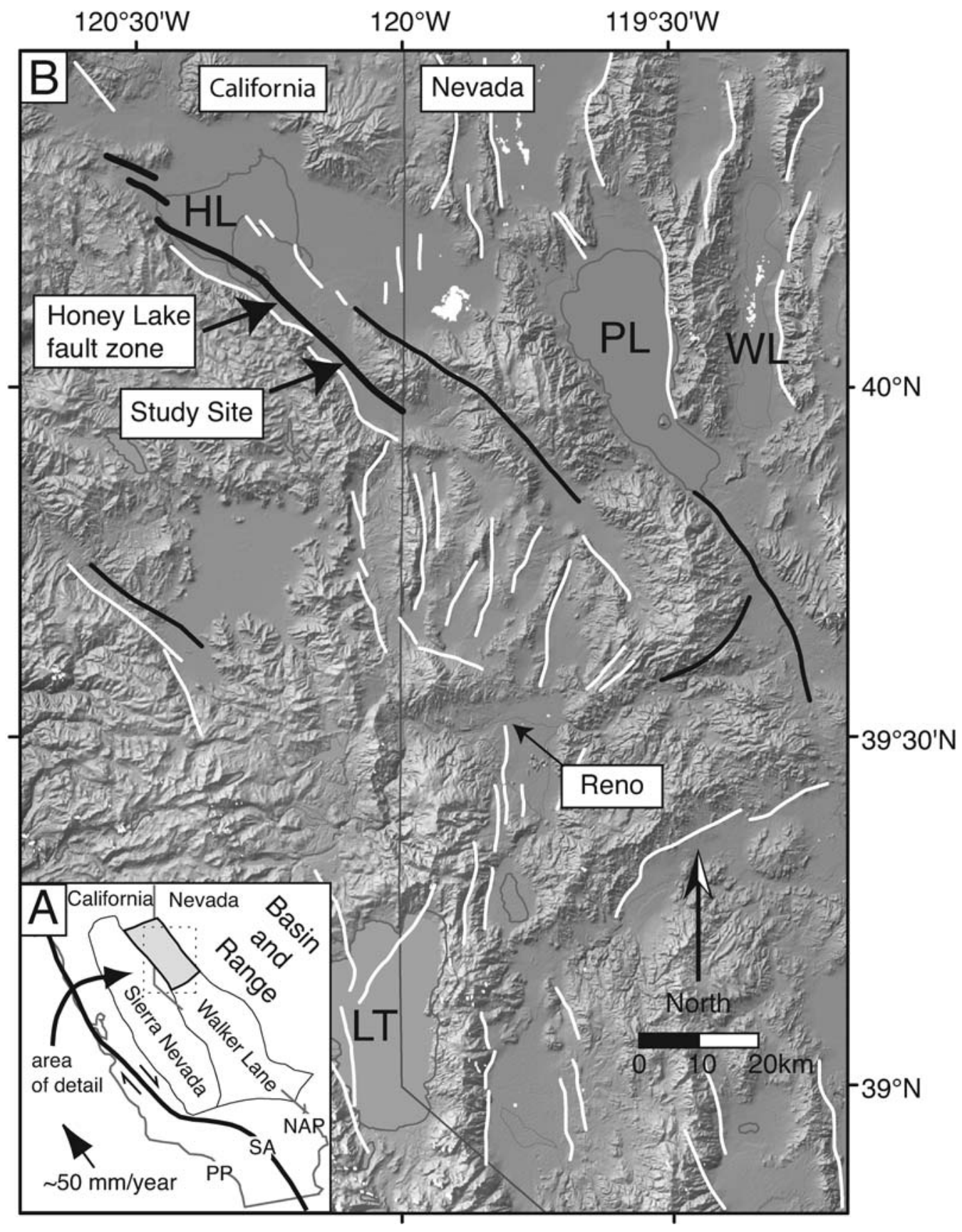

Figure 1. Location of (a) the northern Walker Lane (shaded gray) with respect to the Pacific plate (denoted PP), the San Andreas fault (denoted SA), the North American plate (denoted NAP), the Sierra Nevada, and the Basin and Range province. Plate velocity ( 50 mm/yr) is for the Pacific plate relative to stable North America. Measured geodetically, the Northern Walker Lane is accumulating about $6 \pm 2 \mathrm{~mm} / \mathrm{yr}$ of relative right-lateral motion. (b) The Honey Lake fault zone. Strike-slip faults are black and normal faults are white. The Honey Lake (denoted HL), Pyramid Lake (denoted PL), and Winnemucca Lake (denoted WL) subbasins of Lake Lahontan and Lake Tahoe (denoted LT) are labeled. Faults are simplified and generalized from the USGS (2006), and shaded relief generated from 3' SRTM data are courtesy of NASA/ NGA/USGS.

of the outcrop is archived as a (E) supplemental figure in the electronic edition of BSSA, and details of the sedimentological characteristics of each unit are archived in Turner (2006).

Prominent fault strands (Fig. 3, labeled $A-F$ ) displace the generally flat-lying stratigraphy. Evidence for strike-slip motion is recorded by distinct changes in facies thickness across fault strands, such as that observed for unit 7 across fault strand $B$. Reversals in the apparent vertical offset, such as for units 11 and 13 across fault strand $C$, are also characteristic of strike-slip motion. Local down-to-the-southwest motion has resulted in the presence and preservation of the youngest strata on the southwest side of the fault zone and formed southwest-facing scarps on the adjacent terrace and Lahontan lakebed surfaces (Fig. 2). 


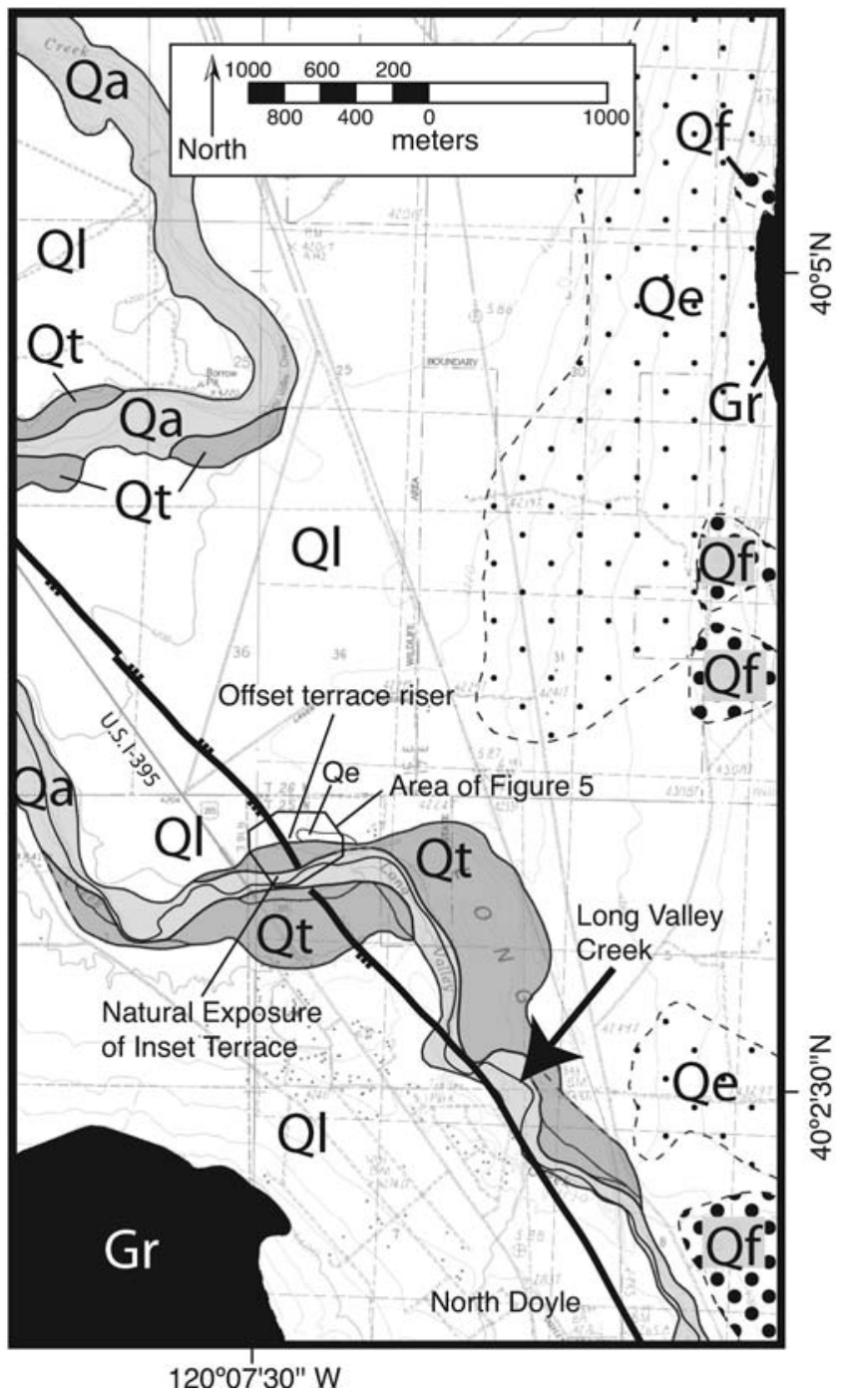

Figure 2. General geologic map showing location of the logged stream-cut exposure and surveyed terrace riser along Long Valley Creek. $Q a$ and $Q t$ are active wash and Holocene terraces, respectively. $Q l$ are aeolian modified lacustrine deposits that predate the desiccation of pluvial Lake Lahontan $(>15,475 \pm 720$ calendar years B.P.; Benson and Thomas, 1987; Adams and Wesnousky, 1998). $Q e$ and $Q f$ are eolian sand sheets and alluvial fans, respectively. $G r$ is Mesozoic granite. The base map is reduced from the Doyle and McKesick Peak 7.5' USGS topographic quadrangles. Study site detail is shown in Figure 5.

Stratigraphic and structural evidence for individual paleoearthquakes is recorded by the relative displacements of well-defined, fine-grained fluvial and overbank sediments (units 1-16) and vertical terminations of individual fault strands $A-F$ (Fig. 3). We identify at least four surfacerupturing earthquakes $(E 1-E 4)$. The youngest surface rupture, $E 1$, is recorded along fault strands $B$ and $D$. These strands reach highest into the section, as each displaces or ruptures into the soil (unit 3) developed on unit 4. Paleoearthquake $E 2$, the penultimate event, is recorded along the western-most major fault strand $A$, which breaks unit 5 but is capped by an unbroken unit 4 (Fig. 3). A yet older dis- placement, surface rupture $E 3$, is preserved along the northeastern-most fault strand $F$, where consistent down-to-thesouthwest displacement offsets unit 9 and the base of unit 7. The normal sense of displacement along strands $D, E$, and $F$ is probably responsible for the presence of a southwest-facing scarp on the terrace tread that has since been buried by the deposition of units $3,4,5$, and 6 on the hanging-wall side of the scarp. On the southwestern hanging-wall side of fault strand $F$, unit 7 grades upward into unit 6 . Unit 6 is nearly identical sedimentologically to unit 7 and is thus interpreted to be colluvial thickening of unit 7 on the hanging wall of the fault associated with displacement on fault strand $F$ during earthquake $E 3$. Finally, the oldest displacement event, $E 4$, is recorded by fault strands $C$ and $E$, which only break units 11 and older and are capped by unbroken unit 9 . Apparent lesser displacement of units 9, 11, and 12 across fault strand $F$ as compared to unit 15 suggests that fault strand $F$ may have also ruptured in older paleoearthquakes.

The timing of surface rupture earthquakes is provided by displaced tephra and charcoal-bearing sediments. The four most recent events, $E 1-E 4$, occurred after deposition of the Tsoyawata tephra at $\sim 7845$ calendar years B.P. (Fig. 3). This is similar to the observations reported at the site by Wills and Borchardt (1993). The timing of individual paleoearthquakes is further constrained by AMS dates of detrital charcoal collected from 4 horizons (Fig. 3, Table 1). We collected four detrital charcoal samples as described in Turner (2006): samples C5, SGW-D, SGW-F, and SGW-G. All event horizons in the exposure postdate deposition of sample C5 (7025 \pm 130 calendar years B.P.) and the underlying Tsoyawata ash in unit 14 (Fig. 4). The oldest surface rupture (E4) occurred after deposition of sample $C 5$ (unit 13) and before deposition of radiocarbon sample SGW-D $(6650 \pm 95$ calendar years B.P.) within units $6 / 7$. Rupture $E 3$ is bracketed by the ages of samples SGW-D (6650 \pm 95 calendar years B.P.) and SGW-G (5560 \pm 85 calendar years B.P.) within unit 5. Event $E 2$ is bracketed by the ages of samples SGW-G $(5560 \pm 85$ calendar years B.P.) and SGW-F (4670 \pm 145 calendar years B.P.) within unit 4 . Surface rupture $E 1$ occurred after deposition of sample SGW-F $(4670 \pm 145$ calendar years B.P.). Fault strands $B$ and $D$ extend into the surface soil, so it is possible that events after $E 1$ have ruptured the fault during the period after $\sim 4670$ calendar years B.P.

The interevent time between events 2 and 3 and events 3 and 4 is between 730 and $990 \mathrm{yr}$ using the median ages of the calibrated age values of the samples (Fig. 4). Given the lack of deposition at the site after $\sim 4670$ calendar years B.P., this record is insufficient to interpret whether such an interevent time is regular and characteristic for the entire mid-to-late Holocene or whether there exists clustering (e.g., Wallace, 1987) or aperiodicity.

\section{Offset Terrace Riser and Fault-Slip Rate}

The Honey Lake fault displaces a fluvial terrace riser between surfaces $Q t$ and $Q l$ immediately northwest of the 


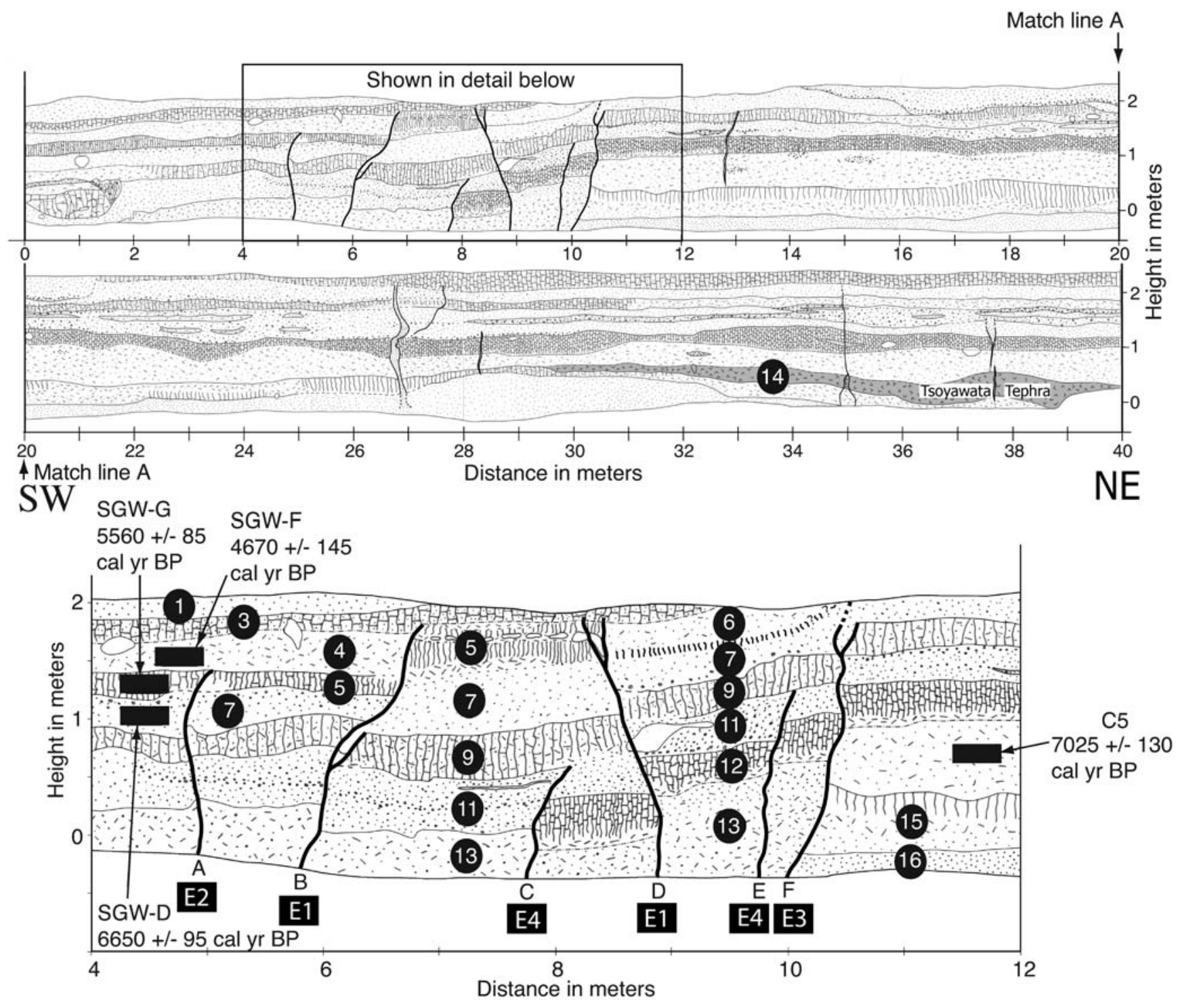

Figure 3. Map of the natural stream-cut exposure of inset terrace deposits. (a) Small-scale map of entire exposure (from Turner, 2006). The Tsoyawata member of the Mazama tephra (7845 \pm 105 calendar years B.P.) is located in the northeast edge of the exposure (shaded gray). Soil development is indicated by a columnar pattern; the extent of soil development is depicted by the thickness of the pattern. (b) Detailed map of the fault zone. Fault strands are labeled $A-F$, sedimentary unit numbers are indicated by circles, and event interpretations are indicated by boxes located below the associated fault strands. Radiocarbon sample positions (black rectangles) and calibrated ages are shown.

natural stream exposure (Figs. 2 and 5). Vertical separation of the scarp is approximately $1 \mathrm{~m}$ on the younger inset $Q t$ surface and approximately $2.5 \mathrm{~m}$ on the older $Q l$ surface (Fig. 5). Right-lateral offset of the terrace riser was estimated at $16 \pm$ $2 \mathrm{~m}$ by Wills and Borchardt (1993). This value was used to estimate a Holocene slip rate of between 1.1 and $2.6 \mathrm{~mm} / \mathrm{yr}$. Because the modern slip rate is an important component of seismic hazard maps (Frankel et al., 2002) and regional tectonic studies, we revisited the feature to construct a detailed (0.5-m contour interval) topographic map of the offset (Fig. 5). The survey measurements, in conjunction with the radiocarbon dates reported in the previous section, provide the basis for discussion of the uncertainties associated with the measured offset and a refinement of the fault slip rate.

The terrace riser separating the $Q t$ and $Q l$ surfaces trends westerly. It is displaced right laterally and dropped down to the west at the fault trace. Measurement of the amount of lateral offset is complicated by three factors. First, the terrace riser was curved prior to fault displacement. Second, colluviation at the junction where the terrace riser intersects the fault scarp has modified the original trend of the riser. This requires that any estimate of the terrace riser offset be extrapolated from points some distance away from the fault. Finally, active dunes ( $Q e$, Fig. 5) obscure the crest of the terrace riser east of the fault and thus complicate 
Table 1

Radiocarbon Data from Natural Stream-Cut Exposure Site along Long Valley Creek

\begin{tabular}{cccccc}
\hline Sample & Lab Number & $14 C$ Age $^{*} \pm 1 \sigma$ & $\partial 13 C$ Age $^{\dagger}$ & ${\text { Calendar Years Before Present }(2 \sigma \text { Range })^{\ddagger}}^{*}$ & Calendar Dates ( $2 \sigma$ Range $)$ \\
\hline SGW-F & 124331 & $4110 \pm 30$ & -25 & $4670 \pm 145$ & $2720 \pm 145$ B.C. \\
SGW-G & 124332 & $4825 \pm 35$ & -25 & $5560 \pm 85$ & $3610 \pm 85$ B.C. \\
SGW-D & 124330 & $5845 \pm 35$ & -25 & $6650 \pm 95$ & $4700 \pm 95$ B.C. \\
C5 & 119750 & $6115 \pm 35$ & -25 & $7025 \pm 130$ & $5080 \pm 130$ B.C. \\
\hline
\end{tabular}

"Using Libby half-life of $5568 \mathrm{yr}$; this is relative to A.D. 1950.

${ }^{\dagger}$ Assumed values according to Stuvier and Polach (1977) when given without decimal places.

Dendrochronologically calibrated ages calibrated with CALIB (version 5.0.1) (Stuiver and Reimer, 1993; Reimer et al., 2004).

estimation of the elevation of the original $Q l$ surface near the fault.

To quantify the lateral offset recorded by the terrace riser while honoring the geometric uncertainties outlined previously, we initially assume that the $Q l$ surface was flat across the fault prior to tectonic offset. The 1270.5 and $1267-\mathrm{m}$ contours mark the top of the correlative original $Q l$ surface on the foot- and hanging-wall sides of the fault, respectively (Fig. 5). As shown by the shaded region in Figure $5 b$, slope colluvium at the intersection of the terrace riser and fault scarp separates relatively parallel terrace riser contours immediately east and west of the fault scarp. The con- tours that mark our best correlation of offset matching contours are marked by patterned black lines and extrapolated into the fault zone (Fig. 5). Because of erosion as well as dune deposition along the inferred top of the $Q l$ surface east of the fault, our elevation correlations of contours below the inferred $Q l$ surface likely provide the best measure of the horizontal offset. The offsets of the correlated contours average $\sim 5.3 \mathrm{~m}$ right lateral (Fig. 5). An offset of $\sim 10.6 \mathrm{~m}$ is allowable if our correlation of contours is off by one contour interval. In this manner, we arrive at our best estimate of the offset of the inset terrace at between 5.3 and $10.6 \mathrm{~m}$

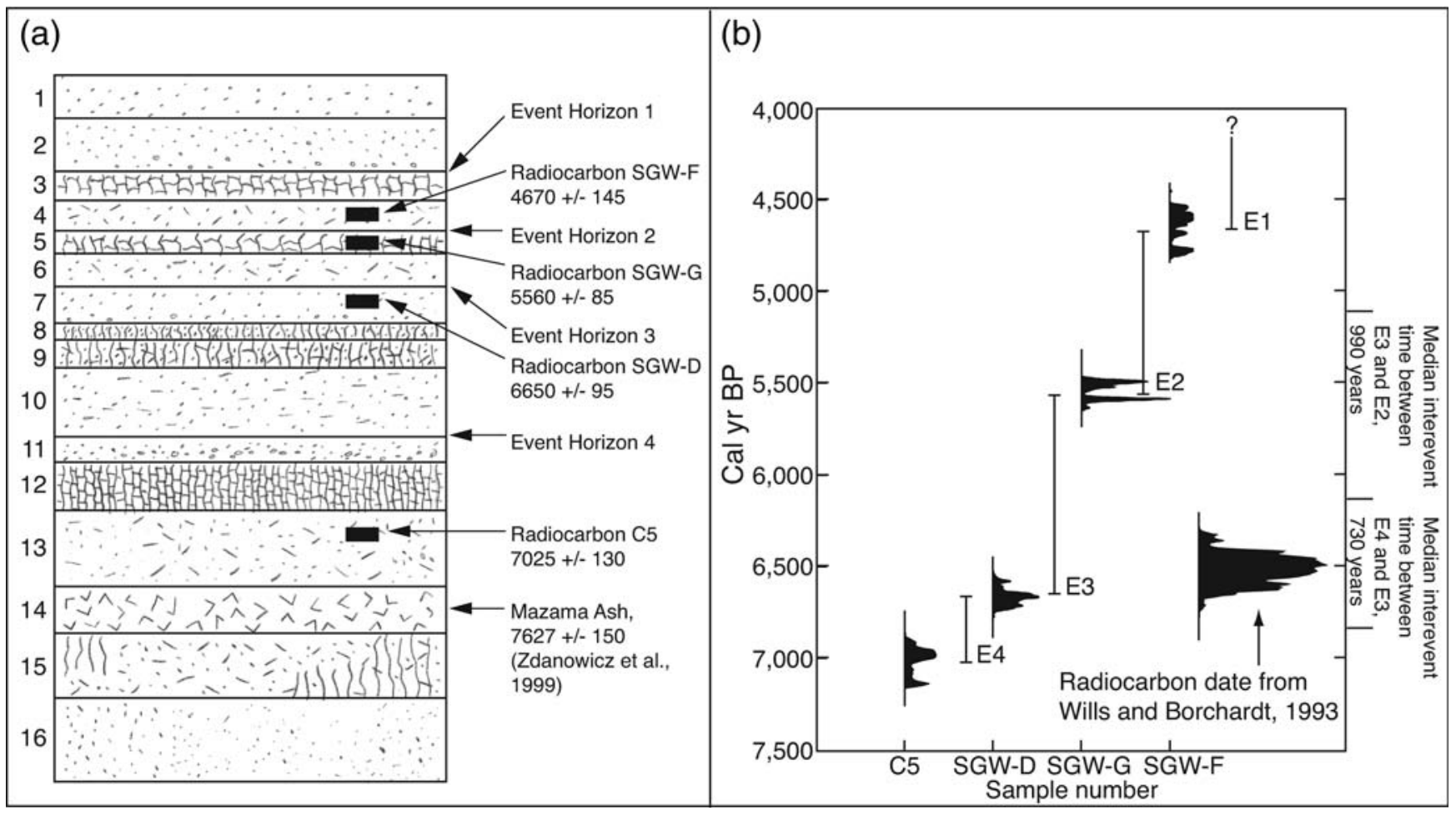

Figure 4. (a) Event horizon diagram shows general stratigraphy, value of detrital radiocarbon ages ( \pm 2 sigma) within respective horizons, and event horizon boundaries. Individual earthquake displacements on fault strands have displaced deposits below the horizon and are capped by undeformed deposits. Radiocarbon ages and Mazama ash ages are reported in calendar years B.P. (Zdanowicz, 1999). Radiocarbon samples are shown as black rectangles. (b) Probability density functions for the respective radiocarbon ages and associated interpreted events as calculated using CALIB version 5.0.1 (Reimer et al., 2004). The probability density function for the radiocarbon date in Wills and Borchardt (1993) is plotted for comparison. Wills and Borchardt (1993) infer the occurrence of four earthquakes in the last 6 ka. Our data also support the occurrence of four earthquakes in a similar amount of time but place tighter constraints on the individual events. 


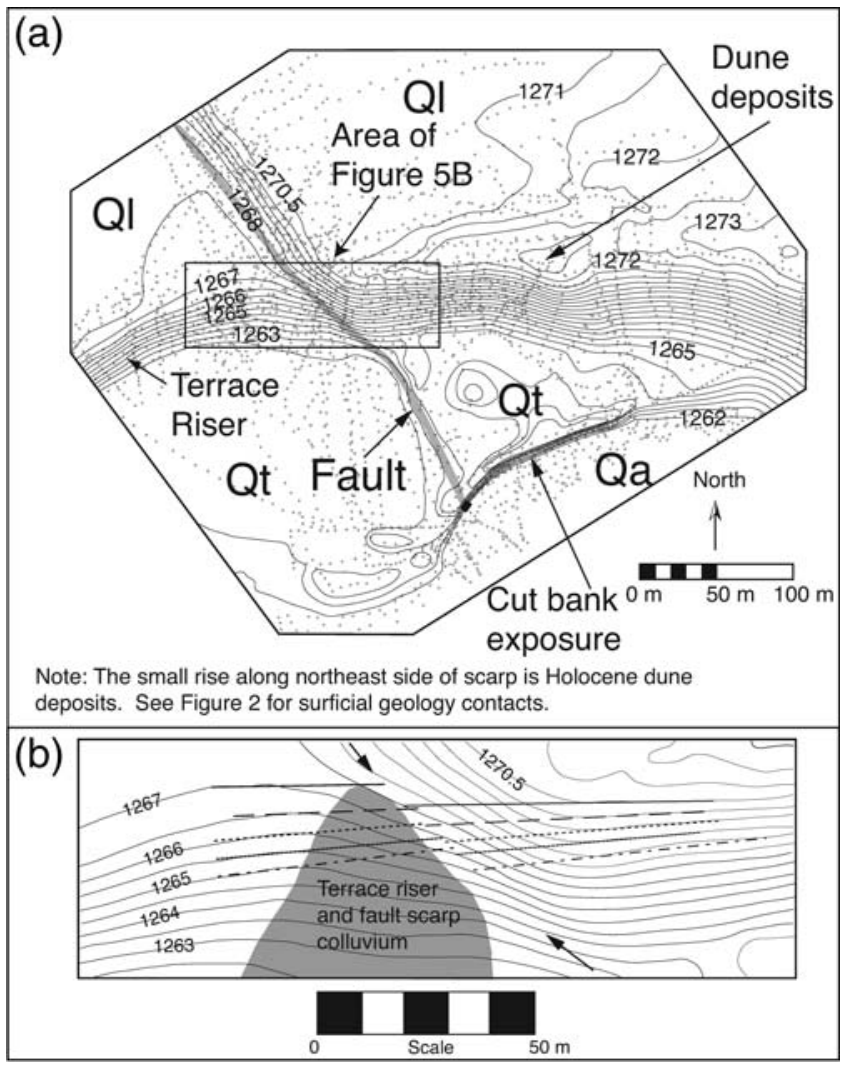

Figure 5. (a) A 0.5-m contour map of the offset terraces and associated riser. Light gray dots indicate Global Positioning System points. The Honey Lake fault is represented by a gray line. Dune deposits occur on the northeast side of the fault and the north side of the terrace riser. (b) Enlarged area depicted within the box in (a). The top of the terrace riser is interpreted to be within the 1267 and $1270.5 \mathrm{~m}$ contours on the west and east sides of the fault, respectively. The surface trace of the fault extends between arrows. Projections of contours across fault scarp are depicted as lines and symbolized to indicate inferred contour correlations (piercing points) used to estimate minimum lateral offset. Lines with the same symbol on either side of the fault are parallel. Maximum offset is estimated by considering a possible mismatch equal to $\sim 0.5 \mathrm{~m}$ (one contour). The shaded region indicates the zone of colluviation between the fault scarp and terrace riser.

The $Q l / Q t$ terrace riser began accumulating displacement after it ceased being actively modified by the adjacent stream channel. This point is clarified when one considers the processes active at the site today. The $Q l / Q t$ riser became a passive marker only when the adjacent $Q t$ surface was abandoned. For example, floods in 1998 cut the modern $Q l / Q a$ riser back more than $4.5 \mathrm{~m}$ (Wills, 2001). Thus, the modern cut banks along Long Valley Creek, including the exposure we logged, will only begin to accumulate displacement when the adjacent active surface (terrace tread below the riser) is abandoned, prohibiting any further erosion of the riser (e.g., Knuepfer, 1988; Van der Woerd et al., 2000). The radiocarbon ages suggest that the inset terrace $(Q t)$ was abandoned as an active deposition surface sometime after $\sim 4670$ calendar years B.P., and, by analogy to active processes today, displacement accumulation on the $Q l / Q t$ riser began only after this time. Dividing the riser offset $(5.3-10.6 \mathrm{~m}$ ) by the maximum age of abandonment of the $Q t$ surface $(4670 \pm 145$ calendar years B.P.) places a minimum bound on the fault slip rate of $1.7 \pm 0.6 \mathrm{~mm} / \mathrm{yr}$.

\section{Discussion and Conclusion}

The acquisition of additional radiocarbon dates has allowed us to refine the paleoseismic history of the Honey Lake fault originally described by Wills and Borchardt (1993). The radiocarbon ages limit the timing of three surface ruptures to between 7025 and 4670 calendar years B.P., with interevent times ranging between 730 and 990 yr. A fourth surface rupture occurred after $\sim 4670$ calendar years B.P. It is possible that there have been additional, younger surface-rupturing earthquakes along the Honey Lake fault that are not apparent from the limited stratigraphy at this site.

A detailed topographic survey limits the right-lateral offset of the terrace riser at Long Valley Creek to about $5.3 \pm 10.6 \mathrm{~m}$. Our observations of modern behavior of the Long Valley Creek channel support the inference that the offset terrace riser became a passive strain marker when the adjacent terrace tread was abandoned. Our radiocarbon ages constrain the age of abandonment of the inset terrace surface to after 4670 calendar years B.P., yielding a minimum Holocene slip rate of $1.7 \pm 0.6 \mathrm{~mm} / \mathrm{yr}$. This slip rate is similar to that reported by Wills and Borchardt (1993) and is consistent with the Honey Lake fault accommodating a major portion of the $4-8 \mathrm{~mm} / \mathrm{yr}$ of right-lateral shear (e.g., Thatcher et al., 1999) measured geodetically across the northern Walker Lane.

\section{Acknowledgments}

This research was supported by the U.S. Geological Survey (USGS), Department of the Interior, National Earthquake Hazards Reduction Program (USGS Award Number 04HQGR121). The views and conclusions contained in this document are those of the authors and should not be interpreted as necessarily representing the official policies, either expressed or implied, of the U.S. Government. We are grateful for the cooperation of Cindy Judd, who permitted us access to her property during our study. We also extend gratitude to Craig DePolo, Chris Wills, and Mark Hemphill-Haley for thoughtful reviews that improved the manuscript. This is a Center for Neoteconic Studies Contribution Number 51.

\section{References}

Adams, K. D., and S. G. Wesnousky (1998). Shoreline processes and the age of the Lake Lahontan highstand in the Jessup embayment, Nevada, Geol. Soc. Am. Bull. 110, no. 10, 1318-1332.

Bacon, (1983). Eruptive history of Mount Mazama and Crater Lake Caldera, Cascade Range, U.S.A., J. Volcanol. Geotherm. Res. 18, $57-115$.

Benson, L. V., and R. S. Thompson (1987). Lake level variation in the Lahontan basin for the past 50,000 years, Quat. Res. 28, 69-85.

Davis, J. O. (1978). Quaternary tephrochronology of the Lake Lahontan area, Nevada and California, in Nev. Archeol. Surv. Res. Pap. No. 7, R. Elston (Series Editor), University of Nevada, Reno, 137 pp. 
Frankel, A. D., M. D. Petersen, C. S. Mueller, K. M. Haller, R. L. Wheeler, E. V. Leyendecker, R. L. Wesson, S. C. Harmsen, C. H. Cramer, D. M. Perkins, and K. S. Rukstales (2002). Documentation for the 2002 update of the national seismic hazard maps, U.S. Geol. Surv. Open-File Rept. 02-420.

Grose, T. T. L., D. L. Wagner, G. L. Saucedo, and M. D. Medrano (1989). Geologic map of the Doyle 15-minute quadrangle, Lassen and Plumas Counties, California, Calif. Div. Mines Geol. Open-File Rept. 89-31, scale $1: 62,500$.

Hinz, N. (2004). Tertiary volcanic stratigraphy of the Diamond and Fort Sage Mountains, northwestern California and western Nevadaimplications for development of the northern Walker Lane, Master's Thesis, University of Nevada, Reno.

Knuepfer, P. L. K. (1988). Estimating ages of late Quaternary stream terraces from analysis of weathering rinds and soils, Geol. Soc. Am. Bull. 100, 1224-1236.

Reheis, M. (1999). Extent of pleistocene lakes in the western Great Basin, U.S. Geol. Surv. Misc. Field Studies Map MF-2323, scale 1:800,000.

Reimer, P. J., M. G. L. Baillie, E. Bard, A. Bayliss, J. W. Beck, C. Bertrand, P. G. Blackwell, C. E. Buck, G. Burr, K. B. Cutler, P. E. Damon, A. G. Hogg, K. A. Hughen, B. Kromer, F. G. McCormac, S. Manning, R. W. Reimer, S. Remmele, J. R. Southon, M. Stuvier, S. Talamo, F. W. Taylor, J. Van der Plicht, and C. E. Weyhenmeyer (2004). IntCal04 terrestrial radiocarbon age calibration, 26-0 ka BP, Radiocarbon 46, no. 3, 1029-1058.

Russell, I. C. (1885). Geological history of Lake Lahontan—a Quaternary lake of northwestern Nevada, American Geophysical Monograph, 11, $288 \mathrm{pp}$.

Stuiver, M., and H. A. Polach (1977). Discussion: reporting of 14C data, Radiocarbon 19, 355-63.

Stuiver, M., and P. J. Reimer (1993). Extended C-14 database and revised CALIB 3.0 C14 age calibration program, Radiocarbon 35, no. 1, 215-230.

Thatcher, W. (2003). GPS constraints on the kinematics of continental deformation, Int. Geol. Rev. 45, 191-212.

Thatcher, W., G. R. Foulger, B. R. Julian, J. L. Svarc, E. Quilty, and G. W. Bawden (1999). Present-day deformation across the Basin and Range province, western United States, Science 283, 1714-1718.
Turner, R. (2006). A late-Pleistocene to Holocene paleoseismic history of the Honey Lake fault, northeastern California and northwestern Nevada, Master's Thesis, University of Nevada, Reno.

U.S. Geological Survey, Nevada Bureau of Mines and Geology, and the California Geological Survey (2006). Quaternary fault and fold database for the United States, http//earthquake.usgs.gov/regional/qfaults/, last accessed 11 November 2006.

Van der Woerd, J., F. J. Ryerson, P. Tapponnier, A-S. Mériaux, B. Meyer, Y. Gaudemer, R. C. Finkel, M. W. Caffee, G. Zhao, and Xu Zhiqin (2000). Uniform slip-rate along the Kunlun Fault: implications for seismic behaviour and large-scale tectonics, Geophys. Res. Lett. 27, no. $16,2353-2356$.

Wagner, D. L., G. J. Saucedo, and T. L. T. Grose (1989). The Honey Lake fault zone, northeastern California, its nature, age and displacement (abstract), Eos Trans. AGU 70, no. 43, 1358.

Wallace, R. E. (1987). Grouping and migration of surface faulting and variations of slip rate on faults in the Great Basin Province, Bull. Seismol. Soc. Am. 77, 868-876.

Wills, C. J. (1990). Honey Lake and related faults, Lassen County, Calif. Div. Mines Geol, Fault Eval. Rept, FER-214, scale 1:24,000, 17 pp.

Wills, C. J. (2001). Stop 3, in Friends of the Pleistocene Pacific Cell Field Trip Guidebook, Northern Walker Lane and Northeastern Sierra Nevada, October 12-14, Adams, K., R. Briggs, B. Bull, D. Granger, A. Ramelli, C. Riebe, T. Sawyer, J. Wakabayashi, and C. J. Wills (Contributors), 23-25.

Wills, C. J., and G. Borchardt (1993). Holocene slip rate and earthquake recurrence on the Honey Lake fault zone, northeastern California, Geology 21, 853-856.

Zdanowicz, C. M., G. A. Zielinski, and M. S. Germani (1999). Mount Mazama eruption; calendrical age verified and atmospheric impact assessed, Geology 27, no. 7, 621-624.

Center for Neotectonic Studies

University of Nevada

Reno, Nevada 89557

Manuscript received 15 April 2007 